\title{
Identification of Poxvirus Under Transmission Electron Microscopy During Outbreak Period in Wild Birds, in São Paulo, Brazil
}

\author{
Identificación de Poxvirus por Microscopía Electrónica de Transmisión \\ Durante Período de Brote en Aves Silvestres en São Paulo, Brasil
}

"Catroxo, M. H. B.; "Pongiluppi, T.; "Melo, N. A.; ${ }^{* *}$ Milanelo, L.; ${ }^{* * *}$ Petrella, S.; "Martins, A. M. C. P. F. \& "Rebouças, M. M.

CATroxo, M. H. B.; POngilupPi, T.; Melo, N. A.; Milanelo, L.; Petrella, S.; MARTINS, A. M. C. P. F. \& REBOUÇAS, M. M. Identification of poxvirus under transmission electron microscopy during outbreak period in wild birds, in São Paulo, Brazil. Int. J. Morphol., 27(2):577-585, 2009.

SUMMARY: Avianpox is a highly contagious disease infecting both commercial and wild birds, causing great damages to breeders and breeding. Caused by DNA viruses of the family Poxviridae, genus Avipoxvirus, if manifest through 3 forms, cutaneous, diphtheric and septicemic. In June 2003, during illegal commercialization of Brazilian birds, 800 wild birds (Paroaria dominicana, Sporophila caerulescens and Sporophila albogularis) were apprehended and being forwarded to the CRAS (Wild Animals Recovery Center), Tietê Ecological Park. After one month, birds presented cutaneous lesions in the beak and feet and anorexia, emaciation, locomotion difficulties, diarrhea, dehydration and death. Among the 800 birds, 500 died and 40 these (15 Paroaria dominicana, 15 Sporophila caerulescens and 10 Sporophila albogularis) were sent to the Electron Microscopy Laboratory of the Biology Institute of São Paulo, SP, to investigate viral agents. Scabs and fragments of skin lesions collected of theses birds were processed for transmission electron microscopy utilizing negative staining (rapid preparation), resin embedding and immunocitochemistry techniques. Under the transmission electron microscopy in all the analyzed samples it was visualized two types of poxvirus particles, $\mathrm{M}$ form, with regular spaced thread-like ridges comprising the exposed surface, measuring $280 \times 230 \mathrm{~nm}$; C form or stain-penetrated particle showing the dumbbell-shaped core surrounded by the outer envelope, measuring $360 \times 330 \mathrm{~nm}$. In the ultrathin sections obtained, three types of intracytoplasmic inclusion bodies were encountered: type A or Bollinger body, outlined by membrane, containing in its interior a great number of mature particles, measuring $200 \mathrm{x} 300 \mathrm{~nm}$, revealing the inner dumbbell-shaped core, two lateral bodies and an external envelope. In the type B electron dense inclusions bodies, viral particles budding of dense amorphous material were observed. Fibrillar inclusions constituted by groups of fibrils or lamellae were disposed in groups witch vary from 2 up to 5 e sometimes showed cross striations. A great number of vesicles, on the average measuring $1000 \mathrm{x} 650$ $\mathrm{nm}$, containing in its interior granular material were also visualized. The nuclei were deformed and showed a marginalized chromatin. In the immunocytochemistry technique, the antigen-antibody was strongly enhanced by the dense gold particles over the viruses.

KEY WORDS: Poxvirus; Paroaria dominicana; Sporophila caerulescens; Sporophila albogularis; Transmission electron microscopy.

\section{INTRODUCTION}

Avianpox is an infectious contagious disease affecting domestic and wild birds and transmitted by the poxvirus etiologic agent (Reed \& Schrader, 1989; Yoshikkawa \& Alam, 2002), members of the genus Avipoxvirus, subfamily Chordopoxvirinae, family Poxviridae (Bolte et al., 1999; Van Riper \& Forrester, 2007). The virus has linear doublestranded DNA genomes that vary from about 260 to 309 kbp and encode 260 putative genes. The thickness and density of the outer layer is consistent with one lipid membrane bilayer, the outside of which appears corrugated because of irregular protrusions extending 3 to $5 \mathrm{~nm}$. The internal structure consists of a dumbbell-shaped core and aggregates of heterogeneous material called lateral bodies between the concavities and the outer membrane (Moss, 2007).

\footnotetext{
* Laboratory of Electron Microscopy, Institute Biological of São Paulo, SP, Brazil.

** Tietê Ecological Park, São Paulo, SP, Brazil.

****Adolfo Lutz Institute, São Paulo, SP, Brazil.
} 
The hystopathological analysis presented infected cells characteristically containing large acidophilic intracytoplasmic inclusions called "Bolinger bodies" (Greenacre, 2005).

The clinical expression of the disease varies according to the viral strain, susceptibility of the host and the mode of transmission (Ensley et al., 1978). This transmission involves insects as vectors, the direct contact with aerosols between infected and susceptible birds, the ingestion of contaminated food or water, and contamination by semen (Metz et al., 1985; Ritchie \& Carter, 1995). The infections are most common during later summer and autumn when mosquitoes are more prevalent (Ritchie et al., 1994).

This disease occurs particularly in tropical and subtropical countries (Reed \& Schrader; Yoshikkawa \& Alam). There are three forms of avianpox, cutaneous or dry pox, diphtheric or wet pox, and septicemic. The cutaneous form is the most common and is characterized by nodular proliferative skin lesions on the unfeathered parts of the body, such as eyelids, beak, legs and feet, and in some cases, papules in the peri and infraorbitalis regions, nose, sinus and tongue causing dyspnea or dysphagia. In the diphtheric form, fibronecrotic lesions occur in the membranes of the, upper respiratory tract and esophagus. An acute onset of ruffled plumage, somnolence, cyanosis and anorexia characterize the septicemic form. In the diphtheric and septicemic form a high mortality is observed. Birds can be affected with two forms of the disease at one time. Avian of any age are considered susceptible, although young are most frequently affected (Ritchie et al.).

Avianpoxvirus is one the largest viruses in size and detected worldwide in all species of poultry and in more than 200 species of birds (Bolte et al.; van Riper \& Forrester). The frequency of cases reported has recently increased and involves newly affected birds species, indicating this virus is emergent (Friend et al., 1999).In Brazil, the occurrence of the disease in Passeriformes is rarely related and has been described in Gnorimopsar chopi, Saltator atricollis, Carduelis magellanica, Paroaria coronata and Saltator similis (Catroxo et al., 2006, 2008; Melo et al., 2007, 2008; Oliveira et al., 2008).

Although the illness is controlled for vaccines in commercial bird raising, it is still considered economically expressive (Luschow et al., 2004; Weli et al., 2004).

Transmission electron microscopy is an effective instrument to detect poxvirus in clinical samples. (Nitsche et al., 2006), allowing to identify these agents in various avian species (Docherty et al., 1991; Ostrowski et al., 1995;
Weli et al.; Gülbahar et al., 2005; Catroxo et al., 2006, 2008; Melo et al., 2007, 2008).

Due to lack of data in the literature, the aim of this study was to identify the presence of avian poxvirus in scabs and skin lesions of wild birds (Paroaria dominicana, Sporophila caerulescens and Sporophila albogularis) using transmission electron microscopy techniques.

\section{MATERIAL AND METHOD}

Description of the outbreak. In June 2003, during illegal commercialization of Brazilian birds, 800 wild birds (cowledcardinal, white-throated seedeater and double-collared seedeater) were apprehended and being forwarded to the CRAS (Wild Animals Recovery Center), Tietê Ecological Park. After one month, birds presented cutaneous lesions in the beak and feet, anorexia, emaciation, locomotion difficulties, diarrhea, dehydration and death. Among the 800 birds, 500 died and 40 of these ( 15 cowled-cardinal, 15 whitethroated seedeater and 10 double-collared seedeater) were sent to the Electron Microscopy Laboratory of the Biology Institute of São Paulo to investigate viral agents. Scabs and fragments of skin lesions collected of these birds were processed for transmission electron microscopy utilizing negative staining (rapid preparation), resin embedding and immunocytochemistry techniques.

Negative staining technique (rapid preparation). In the negative staining the scabs and fragments of skin lesions were suspended in phosphate buffer $0.1 \mathrm{M}, \mathrm{pH}$ 7.0. Drops of the obtained suspension were placed in contact with metallic copper grids with carbon stabilized supporting film of $0.5 \%$ collodium in amyl acetate. Next, the grids were drained with filter paper and negatively stained at $2 \%$ ammonium molybdate, pH 5.0 (Brenner \& Horne, 1959; Hayat \& Miller, 1990; Madeley, 1997).

Resin embedding technique.Thin slices of scabs and fragments of skin lesions were fixed in $2.5 \%$ glutaraldehyde in $0.1 \mathrm{M}$, pH7.0 phosphate buffer and pos-fixed in $1 \%$ osmium tetroxide in the same buffer. After dehydration in cetonic series, the fragments were embedded in Spurr resin (González-Santander, 1969; Luft, 1961). Ultrathin sections were cut on the LKB ultratome and mounted on copper grids. The sections were stained by combination of uranyl acetatelead citrate (Watson, 1958; Reynolds, 1963).

Immunocytochemistry technique. At the immunolabeling technique with colloidal gold particles for negative staining, the copper grids were placed in contact with viral suspension 
and, after removing excess with filter paper, the same were put on specific primary antibody drops. After successive washings in PBS drops, the grids were incubated in protein A drops in association with $10 \mathrm{~nm}$ gold particles (secondary antibody). Grids were then contrasted at $2 \%$ ammonium molybdate, pH 5.0 (Knutton, 1995). Observations were made in a Philips EM 208 electron microscope, at $80 \mathrm{kV}$.

\section{RESULTS}

Among the 40 analyzed animals, all of them (100\%) presented in feet, and occasionally in beaks, small yellowishbrown proliferative nodules or scabs of different sizes, characteristic of cutaneous form (Fig. 1, arrow).

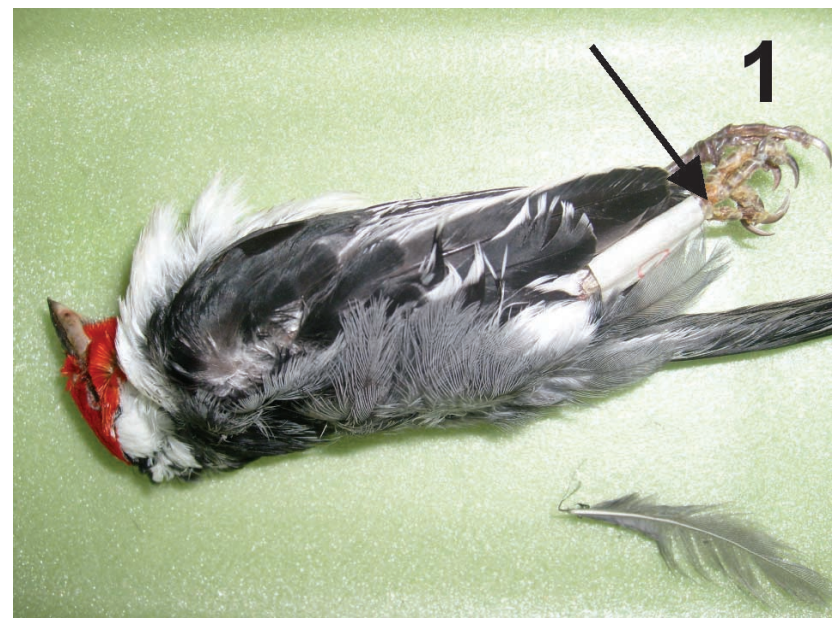

Fig. 1. Paroaria dominicana showing nodular and crusted lesions located in the feets (arrow).

Negative staining technique (rapid preparation). Under the transmission electron microscopy in all the analyzed samples two types of poxvirus particles were visualized, the $\mathrm{M}$ form, with regular spaced thread-like ridges comprising the exposed surface (Fig. 2, big arrow), measuring $280 \times 230$ $\mathrm{nm}$ and the $\mathrm{C}$ form or stain-penetrated particle showing the dumbbell-shaped core (Fig. 2, minor arrow) surrounded by the outer envelope (Fig. 3, arrow), measuring $360 \times 330 \mathrm{~nm}$.

Resin embedding technique. In the ultrathin sections obtained, three types of intracytoplasmic inclusion bodies were encountered. The type A or Bollinger body (Fig. 4), outlined by membrane, containing in its interior a great number of mature particles (Fig. 4, arrow), measuring $200 \mathrm{x}$ $300 \mathrm{~nm}$, revealing the inner dumbbell-shaped core (Fig. 5, big arrow), two lateral bodies (Fig. 5 minor arrow) and an external envelope (Fig. 5, blue arrow). In the type B electron dense inclusions bodies, viral particles budding of dense amorphous material were observed (Fig. 6, arrow). Fibrillar

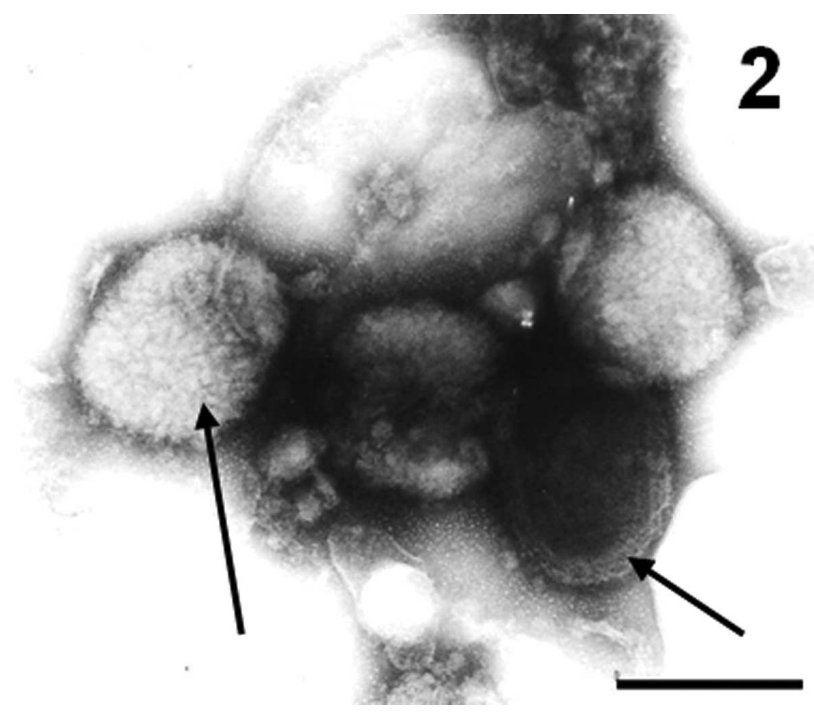

Fig. 2. Negatively stained poxvirus particles showing the M form, with regular spaced thread-like ridges comprising the exposed surface (big arrow) and the Cform or stain-penetrated particle showing the dumbbell-shaped core (minor arrow). Bar $=240 \mathrm{~nm}$.

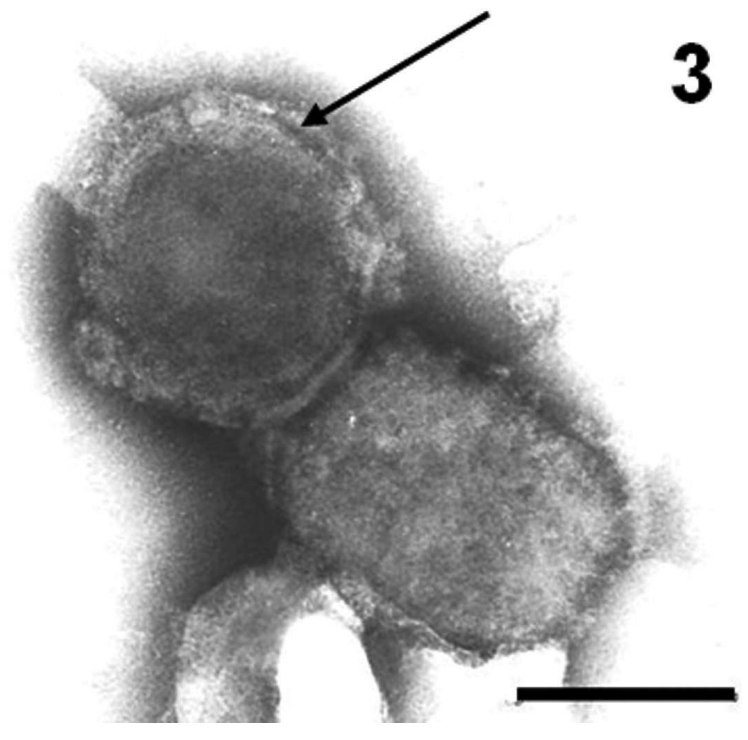

Fig. 3. Negatively stained poxvirus particle showing outer envelope (arrow). Bar $=300 \mathrm{~nm}$.

inclusions constituted by groups of fibrils (Fig. 7, big arrow) or lamellae (Fig. 7, minor arrow) were disposed in groups varying from 2 up to 5 and sometimes showed cross striations. A great number of vesicles, on the average, measuring $1000 \times 650 \mathrm{~nm}$ of diameter, containing in its interior granular material were also visualized (Fig. 8, arrow). The nuclei were deformed and showed a marginalized chromatin (Fig. 9, arrow).

Immunocytochemistry technique. In the immunocytochemistry technique, the antigen-antibody interaction was strongly enhanced by the dense gold particles over the viruses (Fig. 10, arrow). 


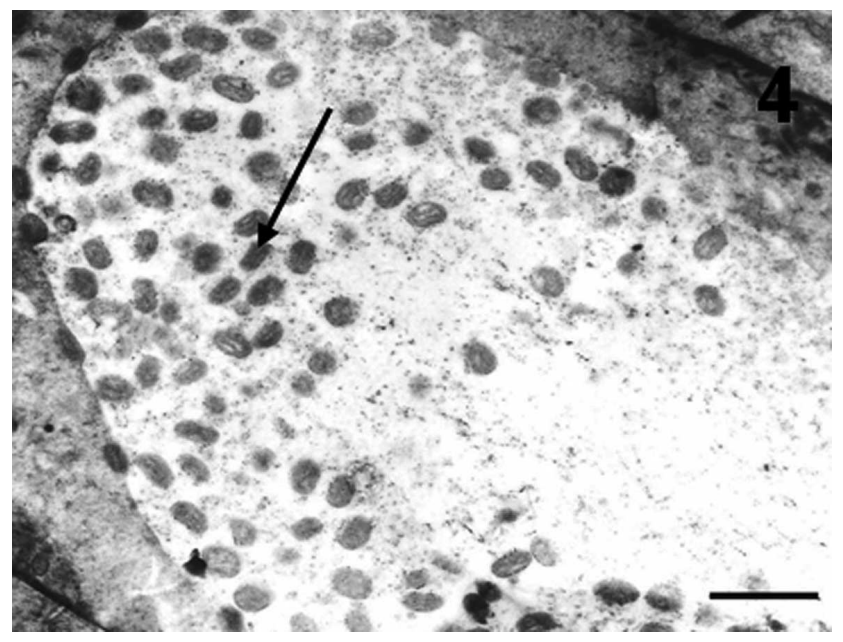

Fig. 4. Ultrathin section of the scabs fragments. Type A or Bollinger intracytoplasmic inclusion bodies, containing in its interior mature particles (arrow). Bar: $1000 \mathrm{~nm}$.

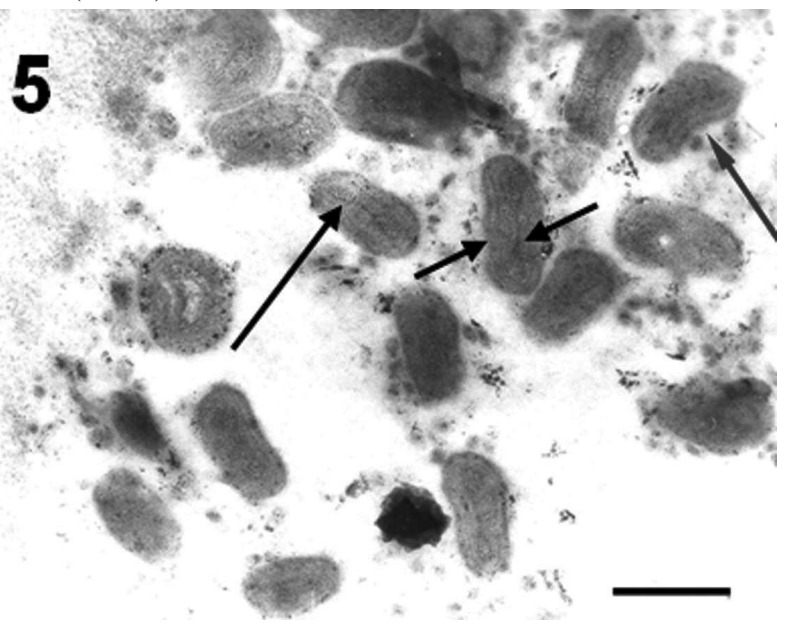

Fig. 5. Ultrathin section of the skin fragments. Mature particles revealing the inner dumbbell-shaped core (big arrow), lateral bodies (minor arrow) and external envelope (blue arrow). Bar: $320 \mathrm{~nm}$.

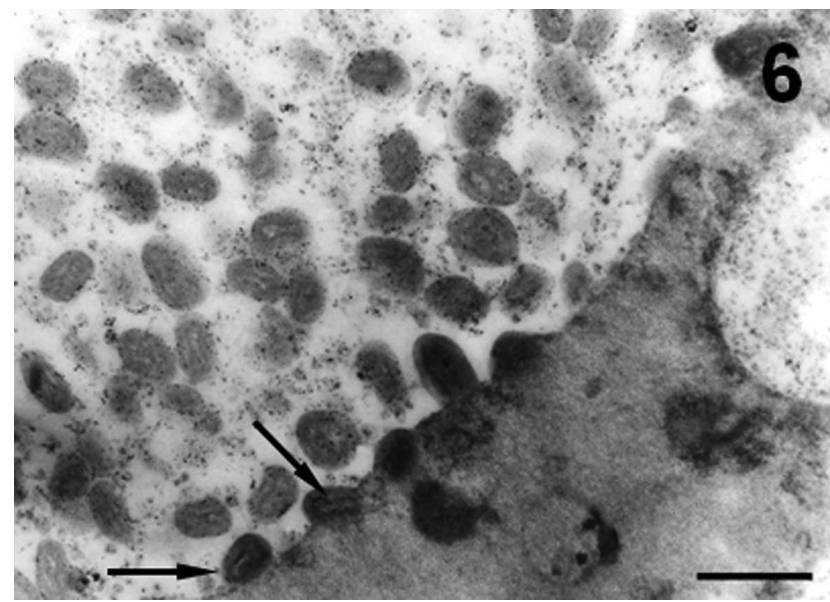

Fig. 6. Ultrathin section of the scabs fragments. Type B electron dense inclusions bodies with viral particles budding of dense amorphous material (arrow).Bar: $600 \mathrm{~nm}$.

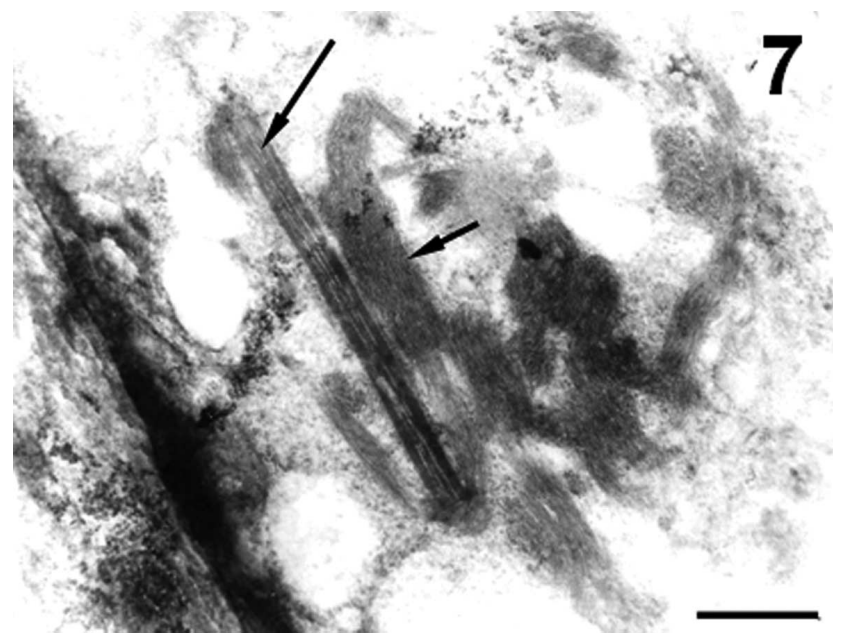

Fig. 7. Ultrathin section of the scabs fragments. Fibrillar inclusions constituted by groups of fibrils (big arrow) or lamellae (minor arrow). Bar: $500 \mathrm{~nm}$.

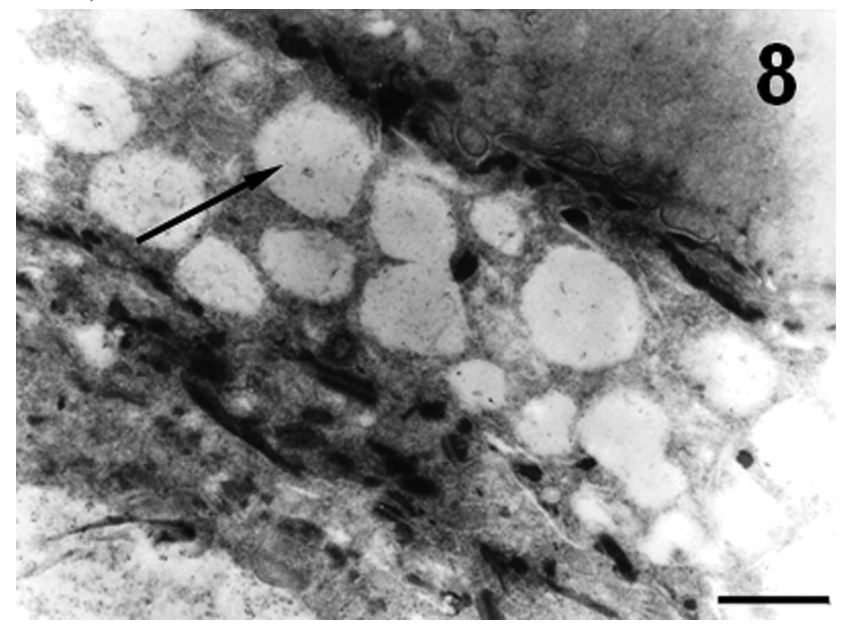

Fig. 8. Ultrathin section of the skin fragments. Vesicles containing in its interior granular material (arrow). Bar: $900 \mathrm{~nm}$.

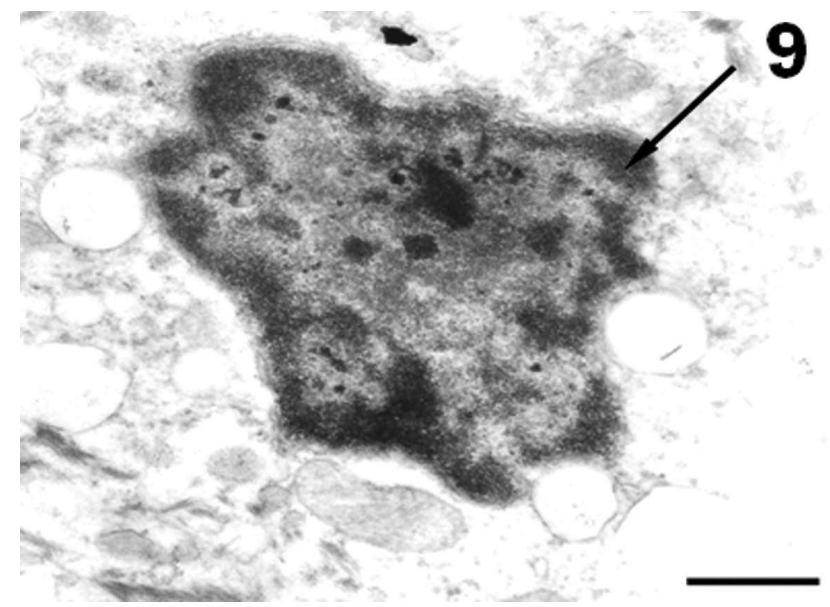

Fig. 9. Ultrathin section of the skin fragments. Nuclei deformed with marginalized chromatin (arrow). Bar: $320 \mathrm{~nm}$. 


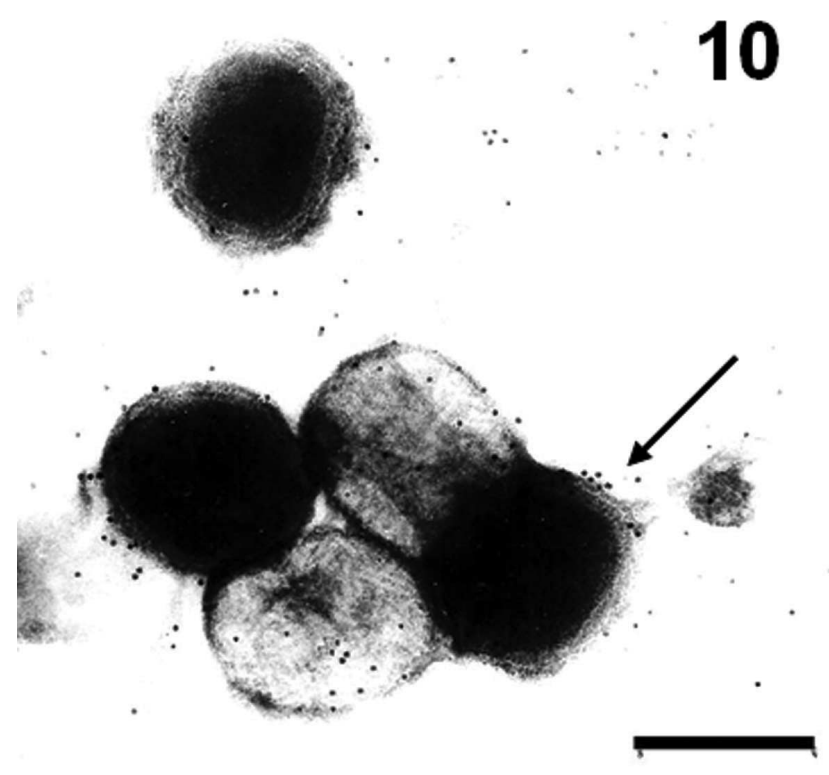

Fig. 10. Immunocytochemistry technique. Antigen-antibody interaction strongly enhanced by the dense gold particles over the viruses (arrow). Bar: $240 \mathrm{~nm}$.

\section{DISCUSSION}

In the present paper, it was observed in feet of the $40(100 \%)$ examined Passeriformes of the Paroaria dominicana, Sporophila caerulescens, Sporophila albogularis species, the presence of nodular proliferative and crusted lesions, characteristics of avianpox lesions, unlike some researches reporting the presence of these lesions in only $2 \%$ up to $50 \%$ of Passeriformes of different species (Trapp, 1980; Senar \& Conroy, 2004; Smits et al., 2005; Catroxo et al., 2006; Oliveira, et al.). Other authors also noted this lesion in the bird feet (Goodpasture \& Anderson, 1961; Trapp; van Riper et al., 2002) eyes, eyelid, crest, beak, ceroma, head, nostrils, neck, legs, wings and abdomen (Alfalluji et al., 1979; Wingate et al., 1980; Docherty \& Long, 1986; Docherty et al., 1991; Reed \& Schrader; Raidal et al., 1996; Deerm et al., 1997; Kreuder et al., 1999) in other birds.

Symptoms like lack of appetite, weight lost, difficulties of locomotion, diarrhea, dehydration and death were seen in all the samples. Similarly, these symptoms were described in species various (McDonald et al., 1981; Gerlach et al., 1998; Ostrowski et al.; Docherty et al.; Fitzner et al., 1985; Kreuder et al.; Catroxo et al., 2006; Oliveira, et al.). Other clinical signs as blindness, blepharitis, conjunctivitis, rhinitis, depression, dyspnea, lethargy, hypothermia and pneumonia were also reported
(McDonald et al., 1981; Boosinger et al., 1982; Nuttal et al., 1985; Raidal et al.; Kreuder et al., 1999; Krone et al.; Medina et al., 2004; Greenacre; Gulbahar et al.; Pledger).

The transmission electron microscopy technique was the elected method to diagnose poxvirus in clinical samples of scabs and skin lesions due to rapid and easy preparation to detect these agents (Fenner et al., 1992; Nistche et al.) and others agents causing vesicular diseases (Hazelton \& Gelderblom, 2003).

By the negative staining technique it was possible to observe that all samples presented a great number of poxvirus particles. In studies with different avian species, the virus was observed in fragments of skin lesions by means of the same technique (Tantawi et al., 1981; Docherty et al.; Allwrigth et al., 1994; Terragino et al., 1999; Weli et al.; Gulbahar et al.; Catroxo et al., 2006).

Our findings by the resin embedding technique showed type A or Bollinger intracytoplasmatic inclusion bodies, containing oval, mature or complete viral particles, measuring on the average, $330 \times 260 \mathrm{~nm}$, revealing an inner dumbbell-shaped core in accordance with other authors (Thiele et al., 1979; Cox, 1980; Wingate et al.; Mc Donald, et al.; Fitzner et al.; Nuttal et al.; Sadosiv et al., 1985; Reed \& Schrader; Deerm et al.; Kreuder et al.; Kim et al., 2003; Smits et al.; Beyut \& Haligür, 2007).

In addition, the observation of immature intracytoplasmatic particles, budding of a dense amorphous material, or type B inclusion body corroborate with other findings in the literature (Purcell et al., 1972; Thiele et al.; Sadosiv et al.). Fibrillar intracytoplasmatic inclusions, constituted by groups of fibrils or lamellae, disposed in groups varying from 2 to 5 , occasionally showing cross striations are in accordance with the reports on swinepox (Bersano et al., 2003; Teppema \& Boer, 1975), the latter mentioning intranuclear inclusion bodies.

Regarding identification of deformed and marginalized chromatin nuclei and the great number of vesicles measuring, on the average, $1000 \times 650 \mathrm{~nm}$, containing granular material on its inner part, were also described by Bersano et al. in cases of swinepox.

The immunocytochemical technique by staining contrast showed positive antigen-antibody interaction with colloidal gold particles enhancing poxvirus agents, confirming the results of the above mentioned techniques. In other experiments with avianpox cases and swinepox, poxvirus particles were enhanced by this technique (Bersano et al.; Catroxo et al., 2006; Melo et al., 2007; Oliveira et al.). 
Proliferation of mosquitoes in the Ecological Park of Tietê, during the summer season, possibly contributes to the appearance of this outbreak in this place. Also, sucking insects, such as mite and others may propagate the disease. (Ritchie et al.; Gustafson et al., 1997).

Prophylactic measures to combat vectors, such as insect window screens, pulverization with insecticides in the raising of birds and isolation of sick birds was proposed by Ritchie et al. (1994).

Stress was described as the main agent responsible by activation of latent infection (Greenacre, 2005). Animals victims of illegal commerce were submitted to varied stress factors.
Avianpox has a worldwide distribution. In Brazil it occurs sporadically in free flying birds, however there is no study in the literature reporting the occurrence of this virus in the three studied strains (Paroaria dominicana, Sporophila caerulescens, Sporophila albogularis).

In this research, detection of poxvirus in these birds by means of transmission electron microscopy allowed to adopt prophylactic and control measures during the outbreak and, it shows the need of a frequent surveillance to detect new cases of avian virus carriers, the protection and preservation of these free flying birds and/or those under threat of extinction and avoiding dissemination of viruses among raising and commercial chicken farms preventing possible economic losses.

CATroXo, M. H. B.; PONGiluPPI, T.; Melo, N. A.; Milanelo, L.; PETRElla, S.; MARTINS, A. M. C. P. F. \& REBOUÇAS, M. M. Identificación de poxvirus por microscopía electrónica de transmisión durante período de brote en aves silvestres en São Paulo, Brasil. Int. J. Morphol., 27(2):577-585, 2009.

RESUMEN: Avianpox es una enfermedad altamente contagiosa que infecta tanto aves comerciales como aves silvestres, causando grandes daños a lo ganadería y a la crianza. Causados por los virus de ADN de la familia Poxviridae, género Avipoxvirus, se manifiestan a través de 3 formas, cutánea, diftérica y septicémica. En junio del 2003, durante la comercialización ilegal de aves brasileñas, 800 aves silvestres (Paroaria dominicana; Sporophila caerulescens; Sporophila albogularis) fueron capturadas y remitidas al CRAS (Centro de Recuperación de Animales Silvestres), Parque Ecológico de Tietê. Después de un mes, las aves presentaron lesiones cutáneas en el pico y las patas, anorexia, adelgazamiento, dificultades de locomoción, diarrea, deshidratación y muerte. 500 de las 800 aves murieron, 40 de éstas (15 Paroaria dominicana, 15 Sporophila caerulescens y 10 Sporophila albogularis) fueron enviadas al Laboratorio de Microscopía Electrónica del Instituto de Biología de São Paulo, SP, para investigar agentes virales. Costras y fragmentos de lesiones en la piel de estas aves fueron recolectadas y se procesaron para microscopía electrónica de transmisión utilizando tinción negativa (preparación rápida), incrustación de resina y técnica inmunocitoquímica. Bajo la microscopía electrónica de transmisión en todas las muestras analizadas se encontraron dos tipos de partículas de poxvirus, Forma M, con espacios regulares como hilo que abarcan toda la superficie expuesta, midiendo 280 × $230 \mathrm{~nm}$; Forma C o partícula teñida por penetración mostrando núcleo en forma de pesa rodeado por una envoltura externa, que medía 360 × $330 \mathrm{~nm}$. Se encontraron en secciones ultrafinas, tres tipos de cuerpos de inclusión intracitoplásmica: el tipo A o cuerpo de Bollinger, esbozado por la membrana, que contiene en su interior un gran número de partículas maduras, que miden 200 x $300 \mathrm{~nm}$, revelando núcleo interno en forma de pesa, dos cuerpos laterales y una envoltura externa. En el tipo B, cuerpos de inclusiones electrodensas, fueron observadas partículas virales brotando de material amorfo de alta densidad. Las inclusiones fibrilares, constituida por grupos de fibrillas o láminas estaban dispuestas en grupos que variaban de 2 a 5 , mostrando estriaciones cruzadas. También fueron observadas un gran número de vesículas, con un promedio de 1000 x $650 \mathrm{~nm}$, conteniendo en su interior material granular. Los núcleos estaban deformados mostrando una cromatina marginal. En la técnica de inmunocitoquímica, la reacción antígenoanticuerpo estaba altamente aumentado por las densas partículas de oro sobre los virus.

PALABRAS ClAVE: Poxvirus; Paroaria dominicana; Sporophila caerulescens; Sporophila albogularis; Microscopía electronic de transmisión.

\section{REFERENCES}

Al Falluji, M. M.; Tantawi, H. H.; Al-Bana, A. \& Al-Sheikhly, S. Pox infection among captive peacocks. J. Wildl. Dis., 15(4):597-600, 1979.

Allwright, D. M.; Burger, W. P.; Geyer, A. \& Wessles, J. Avian pox in ostriches. J. S. Afr. Vet. Assoc., 65(1):23-5, 1994.

Bersano, J. G.; Catroxo, M. H. B.; Villalobos, E. M. C.; Leme, M. C. M.; Martins, A. M. C. P. F.; Peixoto, Z. M. P.; Porugal
M. A. S. C.; Monteiro R. M.; Ogata, R. A. \& Curi N. A. Varíola suína: estudo sobre a ocorrência de surtos nos estados de São Paulo e Tocantins, Brasil. Arq. Inst. Biol., 70(3):269-78, 2003.

Beytut, E. \& Haligür, M. Pathological, immunohisto-chemical, and electron microscopic findings in respiratory tract and skin of chickens naturally infected with avipoxvirus. Turk. J. Vet. Anim. Sci., 31(5):311-7, 2007. 
CATROXo, M. H. B.; PONGILUPPI, T.; MELO, N. A.; MILANELO, L.; PETRELLA, S.; MARTINS, A. M. C. P. F. \& REBOUÇAS, M. M. Identification of poxvirus under transmission electron microscopy during outbreak period in wild birds, in São Paulo, Brazil. Int. J. Morphol., 27(2):577-585, 2009.

Bolte, A. L.; Meurer J. \& Kaleta E. F. Avian host spectrum of avianpoxviroses. Avian Pathol., 28:415-32, 1999.

Boosinger, T. R.; Winterfield, R. W.; Feldman, D. S.; Dhillon, A. S. Psittacinepox virus: virus isolation and identification, transmission and cross-challenge studies in parrots and chickens. Avian Dis., 26(2):437-44, 1982.

Brenner, S. \& Horne, R. W. A negative staining method for high resolution electron microscopy of viruses. Biochim. Biophys. Acta., 34:103-10, 1959.

Catroxo, M. H. B.; Pongiluppi, T.; Milanelo, L.; Rebouças, M. M.; Jesus, T. H.; Cardoso, G. H. M. \& Petrella, S. Detection of poxvirus by transmission electron microscopy using negative staining (rapid preparation) and immunolabelling with colloidal gold particles techniques during outbreak in bay-winged cowbird (Gnorimopsar chopi). Virus Reviews \& Research, 11(suppl.01):101, 2006.

Catroxo, M.H.B.; Melo, N.A.; Milanelo, L.; Rebouças, M.M.; Martins, A.M.C.R.P.F. \& Petrella, S. Detecção de poxvírus aviário em lesões cutâneas de bico-depimenta (Saltator atricollis). In: XXXII Congresso Anual da Sociedade de Zoológicos do Brasil, Sorocaba, S.P., 2008.

Cox, W. R. Avian pox infection in a Canada goose (Branta canadensis). J. Wildl. Dis., 16 (4):623-6, 1980.

Deerm, S. L.; Heard, D. J. \& Fox, J. H. Avian pox in eastern screech owls and barred owls from Florida. J. Wildl. Dis., 33(2):323-7, 1997.

Docherty, D. E. \& Long, R. I. R. Isolation of poxvirus from a house finch, Carpodacus mexicanus (Müller). J. Wildl. Dis., 22(3):420-2, 1986.

Docherty, D. E.; Long, R. I.; Flickinger, E. L. \& Locke, L. $\mathrm{N}$. Isolation of poxvirus from debilitating cutaneous lesions on four immature grackles (Quiscalus sp.). Avian Dis., 35 (1):244-7, 1991.

Ensley, P. K.; Anderson, M. P.; Costello, M. L.; Powell, H. C. \& Cooper, R. Expornitic of avian pox in a zoo. J. Am. Vet. Med. Assoc., 173(9):1111-4, 1978.

Fenner, F., Bachmann, P. A.; Gibbs, E. P. J.; Murphy, F. A.; Studdert, M. J. \& White, D. O. Virologia Veterinaria. Zaragoza, Acribia, 1992.

Fitzner, R. E.; Miller, R. A.; Pierce, C. A. \& Rowe, S. E.
Avian pox in red-tailed hawk (Buteo jamaicensis). $J$. Wildl. Dis., 21(3):298-301, 1985.

Friend, M.; Franson, J. C. \& Ciganovich, E. A. (Eds). Field Manual of Wildlife Diseases: General Field Procedures and Diseases of Birds. Washington, Ed. Washington D. C., United States Geological Survey, 1999. pp.163-70.

Gerlach, H.; Ramis, A.; Enders, F.; Caseres, M. \& Truyen, U. Avian pox in lories (Neopsittacus sp.): a case report. Proceedings of International virtual Conferences in Veterinary Medicine: Diseases of Psittacine Birds. Avaliable: http://www.vet.uga.edu/vpp/ivcvm/1998/ gerlach02/index.php, 1998.

Gonzalez-Santander, R. Técnicas de microscopia electrónica en biología. Madrid, Ed. Aguilar, 1969. p.666.

Goodpasture, E. W. \& Anderson, K. Isolation of a wild avian pox virus inducing both cytoplasmatic and nuclear inclusions. Am. J. Pathol., 40(4):437-53, 1962.

Greenacre, C. B. Viral diseases of companion birds. Vet. Clin. North Am. Exot. Anim. Pract., 8(1):85-105, 2005.

Gülbahar, M. Y.; Çabalar, M. \& Boynukara, B. Avipoxvirus infection in quails. Turk. J. Vet. Anim. Sci., 29:449-54, 2005.

Gustafson, C. R.; Bickford, A. A.; Cooper, G. L. \& Charlton, B. R. Sticktight fleas associated with fowl pox in a backyard chicken flock in California. Avian. Dis., 41(4): 1006-9, 1997.

Hayat, M. A. \& Miller, S. E. Negative Staining. McGrawHill Publ. Company, 1990. p.235.

Hazelton, P. R. \& Gelderblom, H. R. Electron microscopy for rapid diagnosis of emerging infectious agents in emergent situations. Emerg. Infect. Dis., 9(3):294-303, 2003.

Kim, T. J.; Schnitzlein, W. M.; McAloose, D.; Pessier, A. P. \& Tripathy, D. N. Charactarization of an avianpox virus isolated from an Andean condor (Vultur gryphus). Vet. Microbiol., 96(3):237-46, 2003.

Knutton, S. Electron microscopical methods in adhesion. Methods. Enzymol., 253:145-58, 1995.

Kreuder, C.; Irizarry-Rovira, A. R.; Janovitz, E. B.; Deitschel, P. J. \& De Nicola, D. B. Avian pox in sanderlings from Florida. J. Wildl. Dis., 35(3):582-5, 1999. 
CATROXo, M. H. B.; PONGILUPPI, T.; MELO, N. A.; MILANELO, L.; PETRELLA, S.; MARTINS, A. M. C. P. F. \& REBOUÇAS, M. M. Identification of poxvirus under transmission electron microscopy during outbreak period in wild birds, in São Paulo, Brazil. Int. J. Morphol., 27(2):577-585, 2009.

Krone, O.; Essbauer S.; Wibbelt, G.; Isa, G.; Rudolph, M. \& Gough R. E. Avipoxvirus infection in peregrine falcons (Falco peregrinus) from a reintroduction programme in Germany. Vet. Rec., 154(4):110-3, 2004.

Luft, J. H. Improvements in an epoxy resin embedding methods. J. Biophys. Biochem. Cytol., 9:409-14, 1961.

Lüschow, D.; Hoffmann, T. \& Hafez, H. M. Differentiation of avian poxvirus strains on the basis of nucleotide sequences of $4 \mathrm{~b}$ gene fragment. Avian Dis., 48:45362, 2004.

McDonald, S. E.; Lowenstine, L. J. \& Ardans, A. A. Avian pox in blue-fronted Amazon parrots. J. Am. Vet. Med. Assoc., 179(11):1218-22, 1981.

Madeley, C. R. Origins of electron microscopy and virus diagnosis. J. Clin. Pathol., 50(6):454-6, 1997.

Medina, F. M.; Ramírez, G. A. \& Hernández, A. Avian pox in white-tailed laurel-pigeons from the Canary Islands. J. Wildl. Dis., 40(2):351-5, 2004.

Melo, N. A.; Lopes; D.; Milanelo, L.; Rebouças; M. M.; Jesus, T. H.; Petrella, S. \& Catroxo, M. H. B. Presença de poxvírus em lesões cutâneas de pata do cardeal (Paroaria coronata). Biológico, 67(1):29, 2007.

Melo, N. A.; Milanelo, L.; Oliveira, A. C.; Rebouças, M. M.; Martins, A. M. C. R. P. F.; Petrella, S. \& Catroxo, M. H. B. Detecção de avipoxvírus em lesões cutâneas de pintassilgo (Carduelis magellanicus) utilizando técnicas de microscopia eletrônica de transmissão. VI Congresso de Iniciação Científica em Ciências Agrárias, Biológicas e Ambientais, São Paulo, S. P., 2008.

Metz, A. L.; Hatcher, L.; Newman, A. J. \& Halvorson, D. A. Venereal pox in breeder turkeys in Minnesota. Avian Dis., 29(3):850-3, 1985.

Moss, B. Poxviridae: The viruses and their replication. In: Virology, Philadelphia, USA, $5^{\text {th }}$. Ed. Lippincot Williams \& Wilkins, 2007. pp.2905-75.

Nitsche, A.; Stern, D.; Ellerbrok H. \& Pauli, G. Detection of infectious poxvirus particles. Emerg. Infec. Dis., 12(7):1139-41, 2006.

Nuttall, P. A.; Brooke, M. D. \& Perrins, C. M. Poxvirus infection of the Manx shearwater (Puffinus puffinus). J. Wildl. Dis., 21(2):120-4, 1985.
Oliveira, A. C.; Melo, N. A.; Milanelo, L.; Rebouças, M. M.; Martins, A. M. C. R. P. F.; Petrella, S. \& Catroxo, M. H. B. Occurrence of avianpoxvirus in Saltator similis by transmission electron microscopy. XIV Congresso da Sociedade Brasileira de Biologia Celular, São Paulo, S. P, 2008.

Ostrowski, S.; Dorrestein, G. M.; Ancrenas, M. \& SaintJalme, M. Debilitanting cutaneous poxvirus lesion on two captive houbara bustards (Chlamydotis undulata). Avian Dis., 39(4): 904-11, 1995.

Pledger, A. Avian pox virus infection in a mourning dove. Can. Vet. J., 46(12):1143-5, 2005.

Purcell, D. A.; Clarke, J. K.; McFerran, B. J. \& Hughes, D. A. The morphogenesis of pigeonpox virus. J. Gen. Virol., 15:79-83, 1972.

Raidal, S. R; Gill, J. H. \& Cross, G. M. Pox in ostrich chicks. Aust. Vet. J., 73(1):32-3, 1996.

Reed, W. M. \& Schrader, D. L. Pathogenicity and immunogenesity of mynah pox virus in chickens and bobwhite quail. Poult. Sci., 68(5):631-8, 1989.

Reynolds, E. S. The use of lead citrate at high $\mathrm{pH}$ as an electron-opaque stain in electron microscopy. J. Cell. Biol., 17:208-12, 1963.

Ritchie, B. W. \& Carter, K. Avian viruses: Function and control. Lake Worth. Florida, Ed. Publishing Incorporated, 1995. pp.285-311.

Ritchie, B. W.; Harrison, G. J. \& Harrison, L. R. Avian Medicine: Principles and application. Florida, Ed. Wingers Publishing Inc., 1994. pp.865-74.

Sadosiv, E. C.; Chang, P. W. \& Gulka, G. Morphogenesis of canary poxvirus and its entrance into inclusion bodies. Am. J. Vet. Res., 46(2):529-35, 1985.

Senar, J. C. \& Conroy, M. J. Multi-state analysis of the impacts of avian pox on population of Serins (Serinus serinus): the importance of estimating recapture rates. Anim. Biodiv. Conserv., 27(1):133-46, 2004.

Smits, J. E.; Tella, J. L.; Carrete, M.; Serrano, D. \& López, G. An epizootic of avian pox in endemic short-toed larks (Calandrella rufescens) and Berthelot's pipits (Anthus berthelotti) in the Canary Island, Spain. Vet. Pathol., 42:59-65, 2005. 
CATroxo, M. H. B.; PONGILUPPI, T.; MELO, N. A.; MILANELO, L.; PETRELLA, S.; MARTINS, A. M. C. P. F. \& REBOUÇAS, M. M. Identification of poxvirus under transmission electron microscopy during outbreak period in wild birds, in São Paulo, Brazil. Int. J. Morphol., 27(2):577-585, 2009.

Tantawi, H. H.; Al Sheikhly, S. \& Hassan, F. K. Avian pox in buzzard (Accipiter nisus) in Iraq. J. Wildl. Dis., 17(1):145-6, 1981.

Teppema, J. S. \& de Boer, G. F. Ultrastructural aspects of experimental swinepox with special reference to inclusion bodies. Arch. Virol., 49:151-63, 1975.

Terregino, C.; Catelli, E.; Delogu, M.; Capua, I. \& Tonelli, A. Poxvirus infection in a blue bonnet owls from Florida. J. Wildl. Dis., 145(9):264, 1999.

Thiele, J.; Kiel, H. \& Adolphs, H. D. Avian pox virus. An ultrastructural study on a cherrug falcon. Brief report. Arch. Virol., 62(1):77-82, 1979.

Trapp, J. L. Avian pox in the gray-crowned rosy finck in Alaska. North Am. Birds Bander., 5 (2):146-7, 1980.

van Riper, C., III, and Forrester, D. J. Avian Pox. In: Infectious and parasitic diseases of wild birds. Eds. N. Thomas, B. Hunter \& Atkinson, C. A. Ames, Iowa, Blackwell Publishing Professional, 2007.pp. 131-76.

van Riper III, C.; van Riper, S. G. \& Hansen, W. R. Epizootiology and effect of avian pox on hawaiian forest birds. The Auk., 119(4):929-42, 2002.

Watson, M. L. Staining of tissue sections for electron microscopy with heavy metals. J. Biophyis. Biochem. Cytol., 4:475-8, 1958.

Weli, S. C.; Okeke, M. I.; Tryland, M.; Nilssen, O. \& Traavik, T. Characterization of avipoxviruses from wild birds in Norway. Can. J. Vet. Res., 68(2):140-5, 2004.

Wingate, D. B.; Barker, I. K. \& King, N. W. Poxvirus infection of the white-tailed tropicbird (Phaethon lepturus) in Bermuda. J. Wildl. Dis., 16(4):619-22, 1980.

Yoshikkawa, M. G. T. \& Alam, J. Histopathological studies of fowl pox in Bantams. Int. J. Poult. Sci., 1(6):197-9, 2002.
Correspondence to:

Prof. Dr. Marcia Catroxo

Electron Microscopy Laboratory

Research and Development Center in Animal Health

Biological Institute of São Paulo

Av. Conselheiro Rodrigues Alves, 1252

CEP 04014-002

Vila Mariana, São Paulo, SP

BRAZIL

Email: catroxo@biologico.sp.gov.br

Received: 16-02-2009

Accepted: 23-03-2009 
